\title{
THE HAND HYGIENE AND BACTERIAL COLONIES COUNT OF ICCU' VISITORS HANDS: AS AN INDICATOR FOR NOSOCOMIAL INFECTION PREVENTION
}

\author{
Sammy Erica Malau ${ }^{\mathrm{a}}$, Samuel M. Simanjuntak ${ }^{\mathrm{b}}$, \\ aBandung Adventist Hospital \\ ${ }^{b}$ Faculty of Nursing of Universitas Advent Indonesia
}

\begin{abstract}
Background: Nosocomial infection is gained and transmitted to the hospitalized patients through direct contact with the hands. The World Health Organization explained that one most effective and economical interventions to prevent nosocomial infections is by requiring the hand washing procedures. Purpose: This study aimed to describe the number and kind of bacteria colonies before and after the hand washing procedures, further to determine the difference of number and kind of bacteria colonies on before and after the hand washing procedures. Methods: This study is a pre-experiment with one group pretest-posttest design. The participant included the visitors of the Intensive Cardiology Care Units (ICCU) of Bandung Adventist Hospital. The participants were recruited using convenience sampling method. The study utilized 10 samples and the data was analyzed using SPSS software. Result: The mean of bacterial count before the hand washing was $73.40 \mathrm{cells} / \mathrm{cm}^{2}$, and the mean of bacterial count at after the hand washing was 12.50 cells $/ \mathrm{cm}^{2}$. The Staphylococcus sapropytuicus, Bacillus sp. and Staphylococcus epidermis were also found at the visitors hands. The paired t-test result showed that there were significant differences between the number of bacteria colonies before and after hand washing procedures with $p$-value $=0,002$. Conclusion: The results of the study was a valid evidence for the hospital decision-makers to promote the sustenance of hand washing policy as part of elevating the quality of nursing care and in the same time to promote nosocomial infection prevention program and patient safety.
\end{abstract}

Keywords: hands washing, bacterial count, nosocomial infection prevention 


\begin{abstract}
Abstrak
Latar belakang: Infeksi nosokomial diperoleh dan ditransmisikan ke pasien yang dirawat di rumah sakit melalui kontak langsung dengan tangan. WHO menjelaskan bahwa intervensi yang paling efektif dan ekonomis untuk mencegah infeksi nosokomial adalah dengan mewajibkan prosedur mencuci tangan. Tujuan: Penelitian ini bertujuan untuk mendeskripsikan jumlah dan jenis koloni bakteri sebelum dan sesudah prosedur mencuci tangan, selanjutnya untuk mengetahui perbedaan jumlah dan jenis koloni bakteri pada sebelum dan sesudah prosedur mencuci tangan. Metode: desain penelitian ini adalah kuasi-eksperimen dengan satu kelompok pretest-posttest. Partisipan penelitian ini adalah pengunjung Unit Perawatan Intensif Jantung (ICCU) Rumah Sakit Advent Bandung. Partisipan direkrut menggunakan metode convenience sampling. Penelitian ini menggunakan 10 sampel dan data dianalisis menggunakan perangkat lunak SPSS. Hasil: Rata-rata jumlah bakteri sebelum mencuci tangan adalah $73,40 \mathrm{sel} / \mathrm{cm}^{2}$, dan rata-rata jumlah bakteri pada setelah mencuci tangan adalah $12,50 \mathrm{sel} / \mathrm{cm}^{2}$. Staphylococcus Sapropytuicus, Bacillus sp. dan Staphylococcus epidermis juga ditemukan di tangan pengunjung. Hasil uji paired t-test menunjukkan bahwa terdapat perbedaan yang signifikan antara jumlah koloni bakteri sebelum dan sesudah prosedur mencuci tangan dengan nilai $p=0,002$. Kesimpulan: Hasil penelitian ini adalah bukti yang valid bagi pengambil keputusan di rumah sakit untuk mempromosikan keberlanjutan kebijakan mencuci tangan sebagai bagian dari peningkatan kualitas asuhan keperawatan dan pada saat yang sama mempromosikan program pencegahan infeksi nosokomial dan keselamatan pasien.
\end{abstract}

Kata kunci: cuci tangan, jumlah bakteri, pencegahan infeksi nosokomial

\section{PENDAHULUAN}

Penyakit infeksi masih merupakan penyebab utama tingginya angka kesakitan dan kematian di dunia. Salah satu jenis infeksi adalah infeksi nasokomial, yang dapat diartikan sebagai infeksi yang diperoleh seseorang selama di rumah sakit. Infeksi ini menyebabkan 1,4 juta kematian setiap hari di dunia (Pusat data dan Informasi Persi, 2013).

Selama 10-20 tahun belakangan ini telah banyak penelitian yang dilakukan untuk mencari masalah utama meningkatnya angka kejadian infeksi nasokomial dan di beberapa negara, kondisinya justru sangat memprihatinkan. Infeksi nasokomial ini justru memperlama waktu perawatan dan perubahan pengobatan dengan obat-obatan mahal akibat resistensi kuman. Karena itu di negaranegara miskin dan berkembang, pencegahan infeksi nasokomial lebih diutamakan untuk dapat meningkatkan kualitas pelayanan pasien di rumah sakit (Jannah, Suhartono, Adi, 2016).

Berdasarkan tulisan pada majalah Tempo Interaktif, Menteri Kesehatan Republik Indonesia, Endang Rahayu Sedyaningsih, menyatakan bahwa 
salah satu penyebab utama kematian dan kesakitan di rumah sakit dan fasilitas pelayanan kesehatan lainnya adalah infeksi. Di Indonesia, infeksi merupakan salah satu penyebab utama kematian ibu dan bayi yang baru lahir. Infeksi ini terus meningkat, dari $1 \%$ di beberapa negara Eropa dan Amerika, sampai lebih dari $40 \%$ di Asia, Amerika Latin, dan Afrika. Pasien, petugas kesehatan, pengunjung dan penunggu pasien merupakan kelompok yang beresiko mendapat infeksi nasokomial. Infeksi ini dapat terjadi melalui penularan dari pasien ke petugas, dari pasien ke pasien lain, dari pasien ke pengunjung atau keluarga maupun dari petugas kepada pasien.

Pasien dalam perawatan inap di rumah sakit, baik yang dirawat dengan penyakit dasar tunggal maupun lebih dari satu secara umum mengalami pemenurunan daya tahan tubuh. Dengan rendahnya daya tahan tubuh menjadikan peningkatan kerentanan terjadinya infeksi silang karena kuman-kuman, virus pada pasien tersebut.

Kepmenkes No. 129 tahun 2008 ditetapkan suatu standar minimal pelayan rumah sakit, termasuk di dalamnya pelaporan kasus infeksi nasokomial untuk melihat sejauh mana rumah sakit melakukan pengendalian terhadap infeksi ini. Data infeksi nasokomial dari surveilans infeksi nasokomial di setiap rumah sakit dapat digunakan sebagai acuan pencegahan infeksi guna meningkatkan pelayanan medis bagi pasien (Kepmenkes, 2008).

Menurut pengamatan investigator selama bertugas di ICU, dan perilaku membersihkan tangan pengunjung dan pemakaian alas kaki dari luar ruangan intensif dapat berdampak pada paparan infeksi bagi pasien. Bakteri yang ada di tangan menjadi penghantar infeksi nasokomial bagi pasien yang berada dalam perawatan di ruangan intensif.

Maksud pada penelitian ini adalah untuk mengetahui jumlah dan jenis gram bakteri yang ada pada tangan pengunjung dan tim kesehatan yang bekerja pada Unit Perawatan Intensif Jantung (ICCU) Rumah Sakit Advent Bandung sebagai indikasi pencegahan infeksi nasokomial yang ditimbulkan dari tangan pengunjung dan anggota tim kesehatan saat berada dalam bangsal kritis Rumah Sakit Advent Bandung.

\section{METODE PENELITIAN}

Penelitian eksperimental ini menggunakan two groups comparative design. Populasi dalam penelitian ini adalah petugas medis dan pengunjung bangsal kritis Rumah Sakit Advent Bandung. Objek penelitiannya adalah jumlah bakteri pada telapak tangan petugas medis dan telapak tangan pengunjung bangsal kritis. Simple Random Sampling digunakan dalam memilih sampel penelitian. Sampel pada penelitian ini adalah 5 telapak tangan petugas medis yang melakukan kunjungan perawatan, dan 5 telapak tangan pengunjung di bangsal kritis Rumah Sakit Advent Bandung.

Pengukuran jumlah dan jenis bakteri pada telapak tangan saat sebelum dan sesudah mencuci tangan dilakukan dengan teknik swap yaitu menempelkan telapak tangan pada plat 
agar dan dilakukan inkubasi dengan menggunakan inkubator selama 24 jam di laboratorium. Kemudian dilakukan perhitungan jumlah dan jenis bakteri dengan menghitung keseluruhan jumlah dan jenis koloni bakteri dalam 1 plat agar dengan menggunakan koloni counter (dalam satuan cell/cm2) saat anggota tim kesehatan bekerja dan pengunjung datang di bangsal kritis.

\section{HASIL DAN PEMBAHASAN}

Analisis data pengukuran jumlah bakteri sebelum mencuci tangan menunjukkan bahwa jumlah rata-rata koloni bakteri adalah 73,40 cells $/ \mathrm{cm}^{2}$.

Tabel 1. Jumlah Koloni Bakteri Sebelum Mencuci Tangan

\begin{tabular}{|c|c|c|c|c|c|}
\hline & $\mathrm{N}$ & Minimum & Maximum & Mean & SD \\
\hline Sebelum & & & & & \\
\hline $\begin{array}{l}\text { Mencuci } \\
\text { tangan }\end{array}$ & & 0 & 150 & 73,40 & 51,4 \\
\hline $\begin{array}{l}\text { Valid N } \\
\text { (listwise) }\end{array}$ & & & & & \\
\hline
\end{tabular}

diutarakan oleh WHO (2009) yang menyatakan bahwa tangan telah terkontaminasi dengan banyak kuman, sehingga mencuci tangan adalah cara yang sangat penting dalam pengontrolan infeksi dan menghambat terjadinya infeksi silang dari patogen. McLaws (2015) juga menjelaskan bahwa tangan merupakan bagian tubuh yang paling sering kontak dengan dunia luar dan digunakan untuk melakukan aktivitas sehari-hari, sehingga sangat memudahkan terjadinya kontak dengan mikroorganisme dan berpindah ke objek lain.

Analisis univariat digunakan untuk mencari nilai rata-rata berdasarkan jumlah koloni bakteri sesudah mencuci tangan. Nilai rata-rata dalam penelitian ini dicari dengan menggunakan bantuan SPSS, seperti yang itampilkan pada tabel berikut ini:

Tabel 2. Jumlah Koloni Bakteri Sesudah Mencuci Tangan
Tabel 1 menunjukkan bahwa jumlah rata-rata koloni bakteri sebelum mencuci tangan adalah 73,40 cells $/ \mathrm{cm}^{2}$.

Berdasarkan hasil uji laboratorium yang telah dilakukan dalam penelitian ini, jenis bakteri yang diperoleh sebelum mencuci telapak tangan adalah bakteri gram positif yang terdiri atas bakteri Staphylococcus sapropytuicus, Bacillus sp, dan Staphylococcus epidermis. Hasil penelitian ini selaras dengan yang



Tabel 2 di atas menunjukkan bahwa jumlah rata-rata koloni bakteri sesudah mencuci tangan adalah 12,50 cells $/ \mathrm{cm}^{2}$. Perbedaaan jumlah bakteri saat sebelum mencuci tangan yang dibandingkan dengan saat setelah mencuci tangan dianalisis dengan 
menggunakan paired-test dengan terlebih dahulu melakukan pengujian normalitas dengan menggunakan
Saphiro Wilk test dan mendapati bahwa data dalam normal distribusi.

Tabel 3. Paired t-Test

\begin{tabular}{|c|c|c|c|c|c|c|c|c|}
\hline & \multicolumn{5}{|c|}{ Paired Differences } & \multirow[t]{3}{*}{$\mathrm{t}$} & \multirow[t]{3}{*}{$\mathrm{df}$} & \multirow{3}{*}{$\begin{array}{l}\text { Sig. (2 } \\
\text { tailed }\end{array}$} \\
\hline & \multirow[t]{2}{*}{ Mean } & \multirow[t]{2}{*}{$\begin{array}{c}\text { Std. } \\
\text { Deviation }\end{array}$} & \multirow[t]{2}{*}{$\begin{array}{l}\text { Std. } \\
\text { Error } \\
\text { Mean }\end{array}$} & \multicolumn{2}{|c|}{$\begin{array}{l}\text { 95\% Confidence } \\
\text { Interval of the } \\
\text { Difference }\end{array}$} & & & \\
\hline & & & & Lower & لррег & & & \\
\hline $\begin{array}{l}\text { SEBELUM MENCULI } \\
\text { TANGAN } \\
\text { DAN SESUDAH MENCUCI } \\
\text { TANGAN }\end{array}$ & 60,行 & 42,865 & 13,555 & 30,236 & 91,564 & 4,493 & 马 & , प02 \\
\hline
\end{tabular}

Pada analisis perbedaan dengan paired t-test antara jumlah bakteri pada tangan anggota tim kesehatan dan pengunjung sebelum mencuci tangan dan setelah mencuci tangan menunjukkan perbedaan jumlah koloni dengan nilai $p$-value 0,002. Dengan demikian dapat disimpulkan bahwa terdapat perbedaan yang signifikan antara jumlah koloni bakteri sebelum dan sesudah mencuci telapak tangan pada pengunjung ICCU Rumah Sakit Advent Bandung. Kesimpulannya adalah null hipotesis ditolak dan hipotesis alternatif diterima.

Hasil penelitian ini selaras dengan hasil penelitian yang dilakukan oleh Desiyanto dan Djannah (2013), yang menunjukkan bahwa terdapatnya perbedaan jumlah kuman antara kelompok kontrol (tanpa mencuci tangan) dengan kelompok eksperimen (mencuci tangan) menggunakan cairan antiseptik. Pengurangan jumlah bakteri di tangan juga dipengaruhi oleh jenis sabun atau cairan antiseptik yang digunakan. Ataee, Ataee, , and Salesi (2017) juga mengatakan bahwa dengan mencuci tangan dapat mengurangi jumlah koloni bakteri yang menempel pada tangan, dan mencegah penularan bakteri dan penyakit dari satu orang ke orang yang lain. Di Muzio, Cammilletti, Petrelli, dan Di Simone (2015) menuliskan bahwa metode untuk mengangkat mikroorganisme dari tangan adalah dengan mencuci tangan menggunakan sabun dan dibilas pada air yang mengalir. Rihi Hina, Simanjuntak, Simbolon (2016) juga menambahkan bahwa tindakan mencuci tangan dapat mengurangi bahkan menghilangkan kuman dan bakteri yang menempel pada tangan, jari, serta kuku.

\section{KESIMPULAN DAN SARAN}

Kesimpulan yang diperoleh berdasarkan hasil analisis data mengenai jumlah koloni bakteri sebelum dan sesudah mencuci telapak tangan pada pengunjung ICCU di 
Rumah Sakit Advent Bandung adalah sebagai berikut:

1. Jumlah rata-rata koloni bakteri sebelum mencuci tangan pada pengunjung ICCU di Rumah Sakit Advent Bandung adalah 73,40 cells $/ \mathrm{cm}^{2}$.

2. Jumlah rata-rata koloni bakteri sesudah mencuci tangan pada pengunjung ICCU di Rumah Sakit Advent Bandung adalah 12,50 cells $/ \mathrm{cm}^{2}$.

3. Terdapat perbedaan yang signifikan antara jumlah koloni bakteri sebelum dan sesudah mencuci telapak tangan pada pengunjung ICCU di Rumah Sakit Advent Bandung, dengan nilai pvalue $<0,05$.

Saran-saran yang diajukan peneliti berdasarkan hasil penelitian dan kesimpulan yang telah dipaparkan adalah sebagai berikut:

1. Tim kesehatan yang bekerja di ICU Rumah Sakit Advent Bandung, agar tetap mempertahan tindakan pencanangan mencuci tangan, baik kepada anggota tim maupun kepada setiap pengunjung ICU demi pencegahan infeksi nasokomial.

2. Hasil penelitian ini dapat digunakan oleh peneliti berikutnya, agar dikembangkan dalam penelitian mengenai pencegahan infeksi nasokomial dengan menggunakan metode yang berbeda, seperti perbedaan jumlah bakteri mencuci tangan dengan air mengalir dan mencuci tangan dengan air tergenang.

3. Bagi Profesi keperawatan, agar tetap mempertahankan bahkan melakukan penyuluhan kesehatan yang menekankan bahwa mencuci tangan sangat penting untuk mencegah infeksi nasokomial, sehingga tidak terjadi penularan penyakit baik terhadap sesama profesi maupun non-profesi.

\section{DAFTAR PUSTAKA}

Ardi Desiyanto A. Fajar, Nur Djannah S. (2013). Efektivitas Mencuci Tangan Menggunakan Cairan Pembersih Tangan Antiseptik (Hand Sanitizer) Terhadap Jumlah Angka Kuman. KESMAS, Vol.7, No.2

Ataee A. Ramezan , Ataee $\mathrm{H}$. Mohammad, Tavana M. Ali, and Salesi M., (2017). Bacteriological Aspects of Hand Washing: A Key for Health Promotion and Infections Control. International Journal of Preventive Medecine. Vol. 8, No. 16.

Badan Pengawas Rumah Sakit Kemenkes RI (2008). Standar Pelayanan Minimal Rumah Sakit. http://bprs.kemkes.go.id/v1/uplo ads/pdffiles/peraturan/6\%20KM K\%20No.\%20129\%20ttg\%20Sta ndar\%20Pelayanan\%20Minimal $\% 20$ RS.pdf.

(Diakses 18/03/2017) 
Di Muzio M., Cammilletti V., Petrelli E., Di Simone E. (2015). Hygiene In Preventing Nosocomial Infections: A Nursing Research. Annali di igiene: medicina preventiva e di comunità, Vol. 27, No. 2.

Mary-Louise McLaws (2015). The relationship between hand hygiene and health careassociated infection: it's complicated. Infection and Drug Resistance, No. 8: 7-18.

Nur Jannah, I., Suhartono, Adi, M. Sakundarno (2016). Prevalensi Phlebitis Pada Pasien Rawat Inap Dengan Infus Di RSUD Tugurejo Semarang. Jurnal Kesehatan Masyarakat, Vol. 4, No. 4.

Pusat data dan Informasi Persi, (2013). 1,4 juta Kematian Akibat Infeksi di RS. http://www.pdpersi.co.id/content /news.php?mid=5\&nid=1050\&ca tid=23. (Diakses 20/03/3017).

World Health Organization (2009). HO WHO Guidelines on Hand Hygiene in Health Care: a Summary. https://www.who.int/gpsc/5may/t ools/who_guidelineshandhygiene_summary.pdf. (Diakses 20/03/2017).

Yohana Fresha Rihi Hina Y. Fresha, Simanjuntak M. Samuel, Simbolon I., (2016). Perilaku Mencuci Tangan Mahasiswa Berasrama Dan Derajat
Kebersihan Tangan: Indikasi Program Pencegahan Infeksi Fekal-Oral. Jurnal Skolastik Keperawatan, Vol.2, No. 2. 